\title{
The Impact of Export Volume and GDP on USA's Civil Aviation in between 1980-2012
}

\author{
Salih Kalayci ${ }^{1} \&$ Sabire Yazici $^{1}$ \\ ${ }^{1}$ Institute of Social Sciences, Beykent University, Istanbul, Turkey \\ Correspondence: Salih Kalayci, Institute of Social Sciences, Beykent University, Istanbul, Turkey. Tel: \\ 90-532-782-8990. E-mail: salih.kalayci@ibesra.com
}

Received: October 23, 2015

Accepted: December 8, 2015

Online Published: December 25, 2015

doi:10.5539/ijef.v8n1p229

URL: http://dx.doi.org/10.5539/ijef.v8n1p229

\begin{abstract}
This paper assays how the effect of USA's both export volume and GDP have on civil aviation by implementing econometrical models such as linear regression and Johansen Co-integration tests in order to realize the dimension of its influence. The impact of both export volume and GDP on civil aviation have analyzed between the years 1980 and 2012 in order to make it a parametrical test by using E-Views Programme. According to Johansen cointegration test there is a long term relationship between the variables in between 1980-2012. Furthermore, It has been founded that USA's export volume and GDP have crucial influence on civil aviation according to the E-Views programme results within the periods of 1980-2012.
\end{abstract}

Keywords: linear regression, USA's export volume, USA's civil aviation, Johansen co-integration test, vector error correction, ADF unit root test

\section{Introduction}

Aviation transport sector can never be considered without structural alteration and technological development. The high quality vehicle with low oil consumption, silent and wide capacity plane production influences the airline firm's management perception and it's contents very significantly. Depending on this issue, the emergence of the privatization and partnership of aviation companies have changed the general structure of aviation sector and the relevant market have been dominated by consumer.

The major reason of the USA's effective and efficient Airway Transportation is the liberalization policy in 1978 which is ensured by the government hand. The European Countries had been influenced from USA's liberalization process and to embrace that process the quantity of the market have increased in point of numbers. At that time, notably some former Eastern Soviet countries could not adopt liberalization process of the civil airway transportation. After liberalization process of the airway transportation sector in Europe, the low cost companies have emerged especially in the middle and western Europe. Thus, they expanded the flight network capacity by entering to the other market and they established new partnerships as well. The liberalization process of the European civil aviation sector began in early 1980 and it lasts until at the end of the millenium. Especially, increasing the Pasific-Asian region's GDP and developing the territories trade capacity among Asian countries gave travel opportunities to the middle income households of the continent. Therefore, the growth rate of the air transportation of the Asian-Pasific was around 10\% in 1990s. Depending on that issue, the estimation of the academician regarding Asian Pasific civil aviation will soared at the top of the point in the near future. The majority of the world airports belongs to the governments and usually the investments of the airport is made by governments (Gulen, 2011, p. 101).

\section{Literature Review}

The airway industry is a crucial part of the social economy meanwhile, it plays a vital role in terms of mechanisms of the development economy. The relationship between civil aviation and economic growth have been became the focus point of the both industrial field and research subjects. Since, applying the open economy policy and reforms in China, the civil airway industry has grew up quickly and enduringly. Civil aviation is the modern and contemporary form of the transportation and this concept reflects the countries development level. Besides, the civil aviation is so significant sector to circulate economy and the improvement of the this area mostly depends on the economic level and the degree of inflence activities (Zhang \& Zhu, 2011). 
In the present days, the majority of the Chinese academicians have worked on the relationship between airway transportation and economic growth detaily. Qing (2006) selected 42 cities for his article in order to use detailed data regarding transportation and their domestic economic growth and empirically he intend to demonstrate the concord relationship between economic development level and airway transportation.

Correspondingly, Wei and Ka (2006) mostly worked on civil airport transportation by concentrating on the regional development of the airport center to evaluate its influences to the cities infrastructure and economic development in their article. By the way, the information concerning its regional advantage to the industry and unique attractiveness to the economy was collected from the people where they are closest to center of the air transportation. Consequently, they empirically proved that the advantage of the air transportation to the economy. Roberts, Rose, Heatwole, Wei, Avetisyan, Chan and Maya (2014) pointed out the total GDP effects on passenger port by applying Computable General Equilibrium Model. The results indicated that net total impact of GDP on passenger crossings is $\$ 49.7$ million.

Dobruszkes, Lennert, and Van Hamme (2011) stated that the level of economy in terms of decision power, trade volume, tourism, the main span from an air market and GDP are the fundamental components of air traffic volume in the major European regions. Hu, Xiao, Deng, Xiao, and Wang (2015) executed heterogeneous panel data models to investigate the Granger causal relationship among GDP and domestic air passenger traffic for 29 states of China. As a result of this, empirical findings demonstrate that there is long run co-integration between local air passenger traffic and GDP in China at upcountry level. 1\% increase in civil aviation traffic is contrive to lead an increase of $0.943 \%$ GDP. Liu and Dong (2009) used the VAR model to apprehend the relationship among the GDP and civil aviation transportation index in the period of 1978-2008. Additionally, they also implemented co-integration test, impulse response and variance decomposition and Granger causality test. The results indicated that there is a long term equipoise relationship between domestic economy and the civil air transportation sector. The growth of domestic economy triggers the civil aviation sector.

In the light of these information majority of the academician worked on the relationship between Air transportation and GDP. Major goal of this manuscript is investigating the long-run relationship between USA's civil aviation, GDP and export volume through time series analysis. The total turnover rate of the air transportation and GDP were analyzed by implementing co-integraiton test and vector error correction. Therefore, the relationship between these variables have proved empirically.

\section{Methodology}

Table 1. The effects of USA's export volume on civil aviation in between 1980-2012

\begin{tabular}{|c|c|c|c|c|}
\hline \multicolumn{5}{|c|}{$L N($ Export Volume $) t=\beta 0+\beta 1 L N($ Civil Aviation $) t+u t$} \\
\hline \multicolumn{5}{|l|}{ Dependent Variable: CIVIL_AVT } \\
\hline \multicolumn{5}{|l|}{ Method: Least Squares } \\
\hline \multicolumn{5}{|l|}{ Date: $12 / 01 / 15 \quad$ Time: $15: 19$} \\
\hline \multicolumn{5}{|l|}{ Sample (adjusted): 19812012} \\
\hline \multicolumn{5}{|c|}{ Included observations: 32 after adjustments } \\
\hline \multicolumn{5}{|c|}{ Convergence achieved after 9 iterations } \\
\hline Variable & Coefficient & Std. Error & $\mathrm{t}$-Statistic & Prob. \\
\hline EXP_VOLUME & 0.442322 & 0.119497 & 3.701535 & 0.0009 \\
\hline $\mathrm{C}$ & 18.24001 & 0.565930 & 32.23018 & 0.0000 \\
\hline $\mathrm{AR}(1)$ & 0.840576 & 0.095047 & 8.843800 & 0.0000 \\
\hline R-squared & 0.979579 & Mean dep & & 20.08611 \\
\hline Adjusted R-squared & 0.978171 & S.D. depe & & 0.286640 \\
\hline S.E. of regression & 0.042350 & Akaike in & & -3.396623 \\
\hline Sum squared resid & 0.052013 & Schwarz & & -3.259210 \\
\hline Log likelihood & 57.34597 & Hannan-C & & -3.351075 \\
\hline F-statistic & 695.5556 & Durbin-W & & 1.707733 \\
\hline Prob(F-statistic) & 0.000000 & & & \\
\hline Inverted AR Roots & .84 & & & \\
\hline
\end{tabular}

The data was collected from World Bank's official website. Logarithm was applied to the sample size and the data size is more than $n>30$ in order to make it parametically test. In order to conceive the research questions and hypothesis regarding both their long term relationship and effects of the variables, the linear regression and Johansen cointegration test was used minutely. The civil aviation was determined as depended variable and both 
export volume and GDP was determined as independed variables.

The linear regression analysis has to be implemented in order to answer the reseach questions. E-views programme was used to perform the econometrical models such as Johansen cointegration test and linear regression analysis. AR(1) was added to the model in order to prevent autocorrelation thus residuals were distributed randomly. Export volume was determined as independent variable to comprehend the effect on civil Aviation and the results demonstrated that there is remarkable influence on USA's airway civil transportation which is founded 0.0009 . On the other hand, the expression of @ trend is added to the econometric model via E-views in order to uderstand that there is spurious regression or not. The results of the @ trend is more than 0.05 which proves that there is no pseudo relationship between export volume and civil aviation.

Table 2. The effects of USA's GDP on civil aviation

\begin{tabular}{|c|c|c|c|c|}
\hline \multicolumn{5}{|c|}{$L N(\mathrm{GDP}) t=\beta 0+\beta 1 L N($ Civil Aviation $) t+u t$} \\
\hline \multicolumn{5}{|l|}{ Dependent Variable: CIVIL_AVT } \\
\hline \multicolumn{5}{|c|}{ Method: Least Squares } \\
\hline \multicolumn{5}{|l|}{ Date: $12 / 01 / 15 \quad$ Time: $15: 18$} \\
\hline \multicolumn{5}{|l|}{ Sample (adjusted): 19812012} \\
\hline \multicolumn{5}{|c|}{ Included observations: 32 after adjustments } \\
\hline \multicolumn{5}{|c|}{ Convergence achieved after 5 iterations } \\
\hline $\begin{array}{r}\text { Variable } \\
\end{array}$ & Coefficient & Std. Error & $\mathrm{t}$-Statistic & Prob. \\
\hline GDP & 0.548781 & 0.063805 & 8.600844 & 0.0000 \\
\hline $\mathrm{C}$ & 3.775720 & 1.904848 & 1.982163 & 0.0570 \\
\hline $\mathrm{AR}(1)$ & 0.721930 & 0.133642 & 5.401975 & 0.0000 \\
\hline R-squared & 0.976951 & Mean dependent & & 20.08611 \\
\hline Adjusted R-squared & 0.975361 & S.D. dependent & & 0.286640 \\
\hline S.E. of regression & 0.044993 & Akaike info crite & & -3.275547 \\
\hline Sum squared resid & 0.058707 & Schwarz criterio & & -3.138134 \\
\hline Log likelihood & 55.40875 & Hannan-Quinn c & & -3.229998 \\
\hline F-statistic & 614.5854 & Durbin-Watson s & & 1.285544 \\
\hline Prob(F-statistic) & 0.000000 & & & \\
\hline Inverted AR Roots & .72 & & & \\
\hline
\end{tabular}

The Linear regression results of the table above demonstrated that the effects of the GDP in between 1980-2012 on civil aviation is so considerable and crucial. The probability is 0.0000 which is significant finding. The same procedure is implemented such as the previous Linear Regression Model to solve the problem of spurious regression. The results of the @ trend is more than 0.05 .

Table 3. ADF test results of civil aviation (non-stationary data)

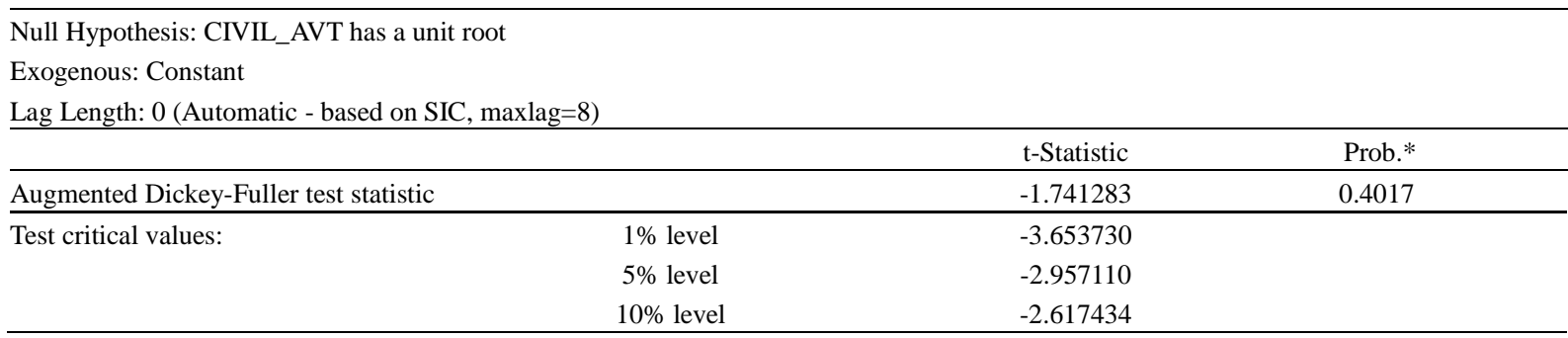

Table 4. ADF test results of export volume (non-stationary data)

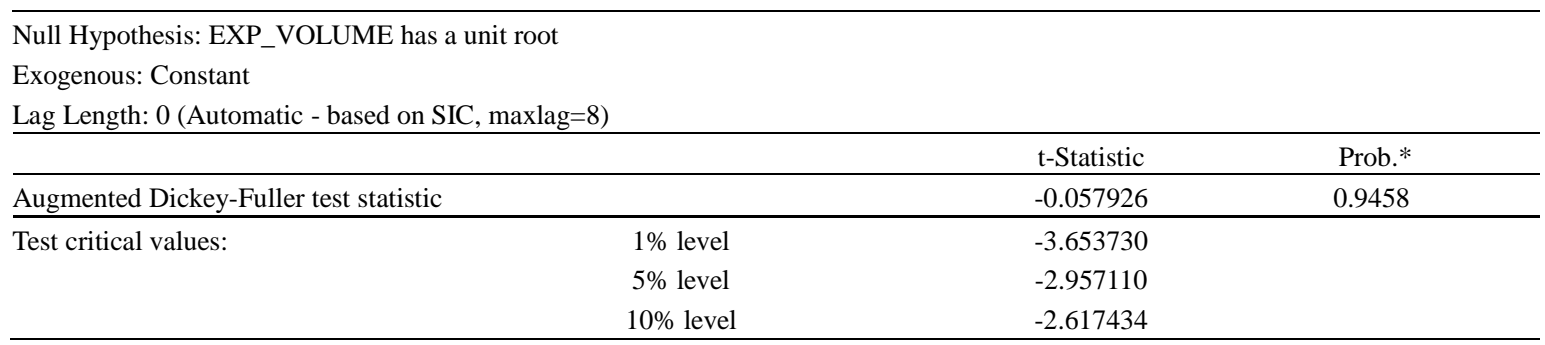


Table 5. ADF test results of GDP (non-stationary data)

\begin{tabular}{|c|c|c|c|}
\hline \multicolumn{4}{|c|}{$\begin{array}{l}\text { Null Hypothesis: GDP has a unit root } \\
\text { Exogenous: Constant } \\
\text { Lag Length: } 1 \text { (Automatic - based on SIC, maxlag=8) }\end{array}$} \\
\hline & & $\mathrm{t}$-Statistic & Prob.* \\
\hline Augmented Dickey-Fuller test statistic & & -2.542989 & 0.1156 \\
\hline \multirow[t]{3}{*}{ Test critical values: } & $1 \%$ level & -3.661661 & \\
\hline & $5 \%$ level & -2.960411 & \\
\hline & $10 \%$ level & -2.619160 & \\
\hline
\end{tabular}

According to ADF results, the data are not stationary. The E-Views programme code was applied to convert them non-stationary to stationary. genr civil_avt $=$ civil_avt - civil_avt (-1), genr exp_volume $=e x p \_v o l u m e-\exp \_v o l u m e(-1)$ ve genr $g d p l=g d p-g d p(-1)$. After converting the data from non-stationary I (0) to stationary I (1), the variables have been put in the Johansen cointegration test and there is long-term relationship between the variables civil aviation, export volume and GDP. The Empirical deductions indicated that the impact of the both export volume and GDP on civil aviation is so remarkable.

Table 6. ADF test results of civil aviation after converting I (0) to I (1) (stationary data)

\begin{tabular}{|c|c|c|c|}
\hline $\begin{array}{l}\text { Null Hypothesis: CI } \\
\text { Exogenous: Constan } \\
\text { Lag Length: } 0 \text { (Auto }\end{array}$ & $\begin{array}{l}\text { Is a unit root } \\
\text { on SIC, ma) }\end{array}$ & & \\
\hline & & t-Statistic & Prob.* \\
\hline \multicolumn{2}{|c|}{ Augmented Dickey-Fuller test statistic } & -4.286204 & 0.0021 \\
\hline \multirow[t]{3}{*}{ Test critical values: } & $1 \%$ level & -3.661661 & \\
\hline & $5 \%$ level & -2.960411 & \\
\hline & $10 \%$ level & -2.619160 & \\
\hline
\end{tabular}

Table 7. ADF test results of export volume after converting I (0) to I (1) (stationary data)

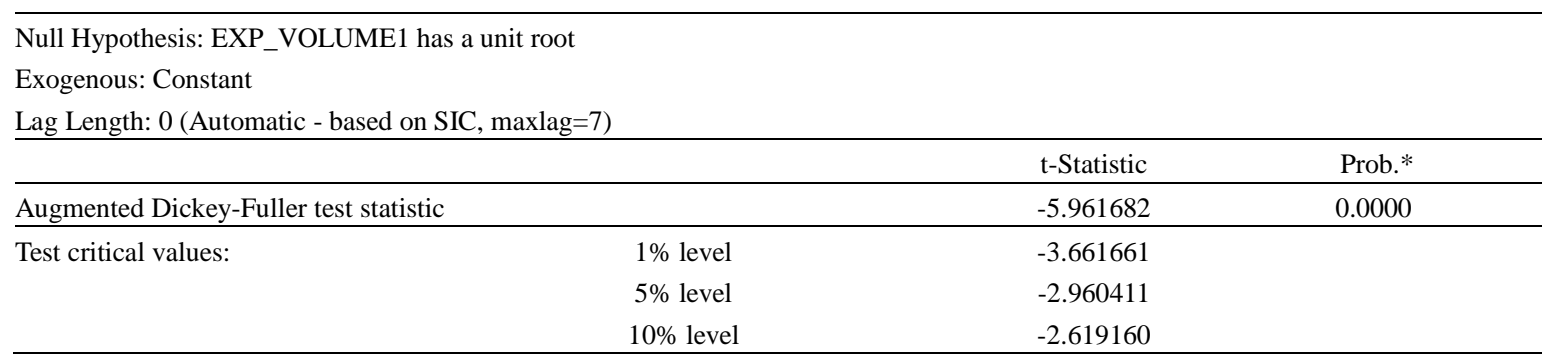

Table 8. ADF test results of GDP after converting I (0) to I (1) (stationary data)

Null Hypothesis: GDP1 has a unit root

Exogenous: Constant

Lag Length: 0 (Automatic - based on SIC, maxlag=7)

\begin{tabular}{lccc}
\hline & & t-Statistic & Prob.* $^{*}$ \\
\hline Augmented Dickey-Fuller test statistic & & -4.077048 & 0.0035 \\
\hline Test critical values: & $1 \%$ level & -3.661661 & \\
& $5 \%$ level & -2.960411 & \\
& $10 \%$ level & -2.619160 & \\
\hline
\end{tabular}


Table 9. Johansen cointegration test

Date: 11/19/15 Time: 18:26

Sample (adjusted): 19832012

Included observations: 30 after adjustments

Trend assumption: Linear deterministic trend

Series: EXP_VOLUME1 CIVIL_AVT1 GDP1

Lags interval (in first differences): 1 to 1

Unrestricted Cointegration Rank Test (Trace)

\begin{tabular}{ccccc} 
Hypothesized & & Trace & 0.05 & \\
No. of CE(s) & Eigenvalue & Statistic & Critical Value & Prob.** \\
None $*$ & 0.527264 & 39.25740 & 29.79707 & 0.0031 \\
At most $1 *$ & 0.375514 & 16.78086 & 15.49471 & 0.0319 \\
At most 2 & 0.084729 & 2.656068 & 3.841466 & 0.1032 \\
\hline
\end{tabular}

Trace test indicates 2 cointegrating eqn(s) at the 0.05 level

* denotes rejection of the hypothesis at the 0.05 level

**MacKinnon-Haug-Michelis (1999) p-values

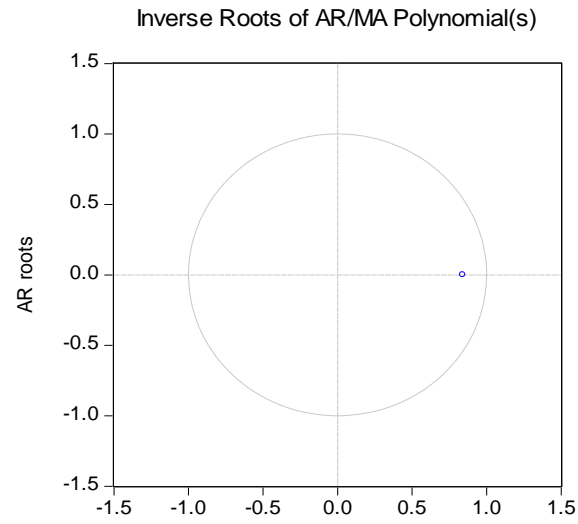

Figure 1. The impact of export volume on civil aviation

The Figure 1 and Figure 2 verified the inverse root of AR/MA polynominals test, all the features of root mean falled within the circles which corrected the linear regression analysis of Table 1 and Table 2 in terms of impact of both GDP and export volume on civil aviation between the period of 1980-2012.

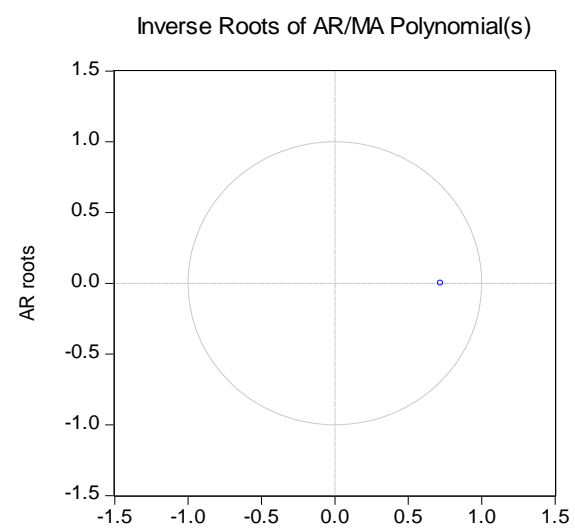

Figure 2. The impact of GDP on civil aviation

The construction of this working paper is as follows: First of all, elaboration of the impact of GDP and export volume on civil aviation via linear regression analysis. Secondly, applying ADF test to convert the data non-stationary to stationary in order to implement Johansen co-integration test. Thirdly, this paper measured the long-run relationship between relevant variables, concluded results and ensured an outlook to future research activities. 


\section{Conclusion}

Johansen cointegration test exhibited that the USA's export volume, GDP and civil aviation have long - term stable equilibrium relationship. The results of the article in terms of the three variables consistent with the Vaziri's and Amirjamshidi's (2008) findings. They handled 31 countries by implementing Gravity model of transportation. The results illustrated the linkage between air distance, trade capacity and its costs. It was concluded that based on the data collected for extrenal trade among the 31 countries, the gravity model of transportation evaluating the distance in the multimodal network as it's impedance factor, best represented the trade. The results of vector error correction verified the long-term relationship between air transportation and export volume. The research examined civil air transportation in relation to both export volume and GDP. The implication of findings indicate that the effect of macroeconomic variables on civil air transportation is so vital. The other factors can be considered as independent variables for new academic workings.

Consequently, since USA's export volume has significant impact on civil aviation within the periods of 1980-2012, p value is 0.0009; Therefore, USA's export volume can clarify the change of the USA's civil aviation through \% 0.9795 prediction rate in between 1980-2012. Furhermore, the effects of USA's GDP on civil aviation $\mathrm{p}$ value is 0.0000 ; The USA's GDP can clarify the change of the USA's civil aviation through \% 0.9769 prediction rate in between 1980-2012. This result consistent with Qing (2006) and Wei and Ka (2006)'s findings which is so crucial to figure out the evaluation process of the air transportation and its parameters. Thus, the growth of the USA's GDP contributed to the R\&D budged and due to that fact, the government invest more in the transportation infrastructure.

Table 10. Data of USA for GDP, civil aviation and export volume

\begin{tabular}{|c|c|c|c|}
\hline$\underline{\text { Year }}$ & $\underline{\text { GDP }}$ & Civil Aviation & Export Volume \\
\hline 1980 & $2,862,500,000,000$ & $295,329,088$ & 35.7 \\
\hline 1981 & $3,210,900,000,000$ & $281,086,400$ & 35.9 \\
\hline 1982 & $3,345,000,000,000$ & $290,992,608$ & 35.2 \\
\hline 1983 & $3,638,100,000,000$ & $315,600,096$ & 35.8 \\
\hline 1984 & $4,040,700,000,000$ & $340,191,488$ & 39.0 \\
\hline 1985 & $4,346,700,000,000$ & $372,059,104$ & 40.8 \\
\hline 1986 & $4,590,100,000,000$ & $414,554,496$ & 41.3 \\
\hline 1987 & $4,870,200,000,000$ & $441,832,704$ & 43.3 \\
\hline 1988 & $5,252,600,000,000$ & $454,202,912$ & 46.5 \\
\hline 1989 & $5,657,700,000,000$ & $453,161,504$ & 49.6 \\
\hline 1990 & $5,979,600,000,000$ & $464,574,016$ & 52.2 \\
\hline 1991 & $6,174,000,000,000$ & $452,015,904$ & 53.5 \\
\hline 1992 & $6,539,300,000,000$ & $466,964,992$ & 55.8 \\
\hline 1993 & $6,878,700,000,000$ & $469,926,112$ & 58.5 \\
\hline 1994 & $7,308,700,000,000$ & $514,924,000$ & 63.6 \\
\hline 1995 & $7,664,000,000,000$ & $533,512,096$ & 69.3 \\
\hline 1996 & $8,100,200,000,000$ & $571,072,000$ & 73.2 \\
\hline 1997 & $8,608,500,000,000$ & $590,571,392$ & 80.1 \\
\hline 1998 & $9,089,100,000,000$ & $588,170,880$ & 84.2 \\
\hline 1999 & $9,665,700,000,000$ & $634,364,608$ & 87.5 \\
\hline 2000 & $10,289,700,000,000$ & $665,327,414$ & 100 \\
\hline 2001 & $10,625,300,000,000$ & $622,187,846$ & 94.0 \\
\hline 2002 & $10,980,200,000,000$ & $598,410,415$ & 90.3 \\
\hline 2003 & $11,512,200,000,000$ & $588,997,110$ & 92.9 \\
\hline 2004 & $12,277,000,000,000$ & $678,110,608$ & 101.1 \\
\hline 2005 & $13,095,400,000,000$ & $720,547,738$ & 108.6 \\
\hline 2006 & $13,857,900,000,000$ & $725,530,965$ & 120.0 \\
\hline 2007 & $14,480,300,000,000$ & $744,302,310$ & 128.1 \\
\hline 2008 & $14,720,300,000,000$ & $701,779,551$ & 135.2 \\
\hline 2009 & $14,417,900,000,000$ & $679,423,408$ & 115.1 \\
\hline 2010 & $14,958,300,000,000$ & $720,497,000$ & 132.7 \\
\hline 2011 & $15,533,800,000,000$ & $730,796,000$ & 142.3 \\
\hline 2012 & $16,244,600,000,000$ & $736,617,000$ & 148.2 \\
\hline
\end{tabular}

Source: World Bank (2015). 


\section{References}

Dobruszkes, F., Lennert, M., \& Van Hamme, G. (2011). An Analysis of the Determinants of Air Traffic Volume for European Metropolitan Areas. Journal of Transport Geography, 19(4), 755-762. http://dx.doi.org/10.1016/j.jtrangeo.2010.09.003

Gulen, K. G. (2011). Status Analysis on Logistic Sector and Comparative Strategies. Istanbul Chamber of Commerce.

Hu, Y., Xiao, J., Deng, Y., Xiao, Y., \& Wang, S. (2015). Domestic Air Passenger Traffic and Economic Growth in China: Evidence from Heterogeneous Panel Models. Journal of Air Transport Management, 42, 95-100. http://dx.doi.org/10.1016/j.jairtraman.2014.09.003

Liu, L. J., \& Dong, W. H. (2009). Empirical Analysis on the Relationship between Civil Aviation Transportation Industry and GDP in China Based on VAR Model. Journal of Finance and Economics, 8, 8.

Qing,Y. W. (2006). The Theory and Practice of Transport Development. Beijing: Chinese Science and China Technology Press.

Roberts, B., Rose, A., Heatwole, N., Wei, D., Avetisyan, M., Chan, O., \& Maya, I. (2014). The Impact on the US Economy of Changes in Wait Times at Ports of Entry. Transport Policy, 35, 162-175. http://dx.doi.org/10.1016/j.tranpol.2014.05.010

The World Bank. (2015a). Export Volume Index. Retrieved from http://data.worldbank.org/indicator/TX.QTY.MRCH.XD.WD

The World Bank. (2015b). Air Transport, Passengers Carried. Retrieved from http://data.worldbank.org/indicator/IS.AIR.PSGR

The World Bank. (2015c). GDP (Current US \$). Retrieved from http://data.worldbank.org/indicator/NY.GDP.MKTP.CD/countries

Vaziri, M., \& Amirjamshidi, G. (2008). A Transport Appraisal of Mineral Fuel Trade for Asia. 6th International Conference on Traffic and Transportation Studies. Beijing-China. http://dx.doi.org/10.1061/40995(322)30

Wei, S., \& Ka, Y. (2006). The Effect of the Civil Aviation Airport on Development of Urban and Regional Economic. Journal of Geography, 6, 649-657.

Zhang, H., \& Zhu, M. G. (2011). An Empirical Research on the Relation between the Air Transportation and Economic Growth. 18th Anuual Conference Proceedings. Rome-Italy. http://dx.doi.org/10.1109/ICMSE.2011.6070033

\section{Copyrights}

Copyright for this article is retained by the author(s), with first publication rights granted to the journal.

This is an open-access article distributed under the terms and conditions of the Creative Commons Attribution license (http://creativecommons.org/licenses/by/3.0/). 